\title{
Studies on Egg Laying Behaviuor and Fecundity under Different Stress Conditions in Tropical Tasar Silk Moth
}

\author{
P. Sudhakara Rao ${ }^{1 *}$, K. M. Vijaya Kumari ${ }^{1}$, B. Sailaja ${ }^{1}$, G. V. Vishaka ${ }^{2}$, \\ S. Vidyunmala ${ }^{1}$ and R. K. Mishra ${ }^{3}$ \\ ${ }^{1}$ Silkworm Seed Technology Laboratory, Central Silk Board, Kodathi, \\ Bengaluru-560035, India \\ ${ }^{2}$ Basic Tasar Silkworm Seed Organization, Bilaspur-495001, India \\ ${ }^{3}$ National Silkworm Seed Organization, Central Silk Board, Bengaluru-560068, India \\ *Corresponding author
}

\begin{tabular}{|c|}
\hline Keywords \\
\hline $\begin{array}{l}\text { Tasar silkworm, } \\
\text { Antheraea mylitta, } \\
\text { fecundity, egg } \\
\text { production and } \\
\text { stress conditions }\end{array}$ \\
\hline Article Info \\
\hline $\begin{array}{l}\text { Accepted: } \\
14 \text { August } 2019 \\
\text { Available Online: } \\
10 \text { September } 2019\end{array}$ \\
\hline
\end{tabular}

\section{Introduction}

The scarcity of good quality eggs for
commercial rearing is one of the important
reasons for the decline in Tasar silk

The scarcity of good quality eggs for
commercial rearing is one of the important
reasons for the decline in Tasar silk

The scarcity of good quality eggs for
commercial rearing is one of the important
reasons for the decline in Tasar silk
Tasar silkworm (Antheraea mylitta Drury) rearing and cocoon production are mainlycarried out by Tribal people of Central India and some parts of Odisha and Telangana states. Lack of Tasar silkworm seed production and preservationtechnology is creating difficulties in timely supply of adequate quantity of seed to the farmers and others stake holders..High temperature above $28^{\circ} \mathrm{C}$ and less relative humidity than $50 \%$ are not suitable for the oviposition and hatching of eggs. In Tasar silk moth, egg retention was also more even after $72 \mathrm{~h}$ of oviposition in natural conditions.In the present investigation, while providing optimum temperature $\left(27-28^{\circ} \mathrm{C}\right)$ and humidity (75-80\%) in the egg laying room, egg laying was carried out in bivoltine and trivoltine broods under different stress conditions. The results indicated that in bivoltines (per5 moths), in T1 where antenna and wings were amputated, the number of eggs recorded were 1306, in T2 (legs and wings cut) it were 902 and in T3 (antenna, wings \& legs cut), the number of laid eggs were 1154 when compared to 907 in Normal conditions (T0) for 5 months. Egg retention results indicated that in T1,itwas 200 amounting to $13.28 \%$ and fecundity was 261 . In T2,it was 145 amounting to $13.85 \%$ and fecundity was 180. In T3, with Antenna, legs \& wings amputation egg retention was 135 amounting to $10.47 \%$ and fecundity of 231.In case of normal moths (T0), egg retention was 124 amounting to $12.03 \%$ with a fecundity of 181 . In case of Trivoltines ( 5 moths) also same pattern was observed. The mentioned stress conditions are useful while grainage operations for getting more fecundity. production. In Tasar culture, pre-seed and seed crops are affected by adverse climatic conditions; diseases and erratic emergence in seed cocoon as a result commercial crops are not getting adequate timely supply of quality 
seed. The rearers are unable to utilize their full potential of natural plantation for rearing during the favorable commercial crops.

Hence, there is a wide gap between the demand and supply of disease free layings. Lack of seed preservation technology and seed multiplication at P2 and P1 level is weakly integrated.

The Central Silk Board (CSB) intervening with technological improvements and producing and supplying basic seed annually to State Departments / other agencies to bring good cocoon production through newly established Basic Tasar Silkworm Seed Organization (BTSSO) and its Basic Seed Multiplication Centers (BSMTCs).

The commercial disease free layings are distributed through private rearers and it is necessary to preserve the produced seed and supply for commercial crops (Singh et al., 2014). The role of temperature and relative humidity on oviposition and incubation of eggs were reported earlier by several workers (Pandeyet al.,2010). The impact of temperature stress on hatching of eggs in Tasar silkworm showed great deal of variation in hatching percentage. High temperature more than $28^{\circ} \mathrm{C}$ and Relative humidity less than $50 \%$ are not suitable for oviposition and hatching of eggs.

The egg retention was also more in Tasar silk moths even after $72 \mathrm{~h}$ of egg laying in natural conditions of egg laying and this is one of the factor for poor fecundity in Tasar silk moth.

Antennae are considered as nostrils in insects to trap odor molecules (Zacharuk, 1985) and contact chemoreception has been studied to induce oviposition in Pieris butterflies by glucosinolates compounds (Chapman, 1998). In this context, the present study was carried out to know egg laying behavior and fecundity under different stress conditions of antennae / wings amputation to realize its full potential.

\section{Materials and Methods}

The required seed cocoons were obtained from CTR\&TI, Ranchi (Daba, bivoltine and Trivoltine broods) during 2016 and preserved under optimum conditions of temperature (27$28^{\circ} \mathrm{C}$ )and humidity $(45-50 \%)$ recommended for seed cocoon preservation (Singh et al., 2014). The bivoltine and trivoltine broods were exposed to the light regime of L: $16 \mathrm{~h}$. (4PM - 8 AM) and D: 8h. (8AM - 4 PM) one month prior to emergence till the completion of grainage operations and moth emergence was recorded under this photo period. (Vemananda Reddy et al.,2015).In the egg laying room optimum temperature $\left(28^{\circ} \mathrm{C}\right)$ and humidity $(80 \%)$ were maintained for better oviposition. The male and female moths were left for 3-4 h coupling (Jolly et al., 1974) and seed production was carried out under different stress conditions i.e.,T1; Antenna\& wings amputated, T2;Legs\&wings amputated and T3; Antenna, wings \& legs amputated and T0 (Normal) and egg laying behavior was observed. The collected eggs were incubated at $25 \pm 1^{\circ} \mathrm{C}$ and relative humidity of $80 \pm 5 \%$ in the SERICATRON (an environmental chamber where required temperature and humidity can be maintained) till hatching and hatching percent was recorded.

\section{Results and Discussion}

In the present study the egg laying behavior and fecundity was observed in bivoltine and Trivoltine broods of Daba race for 5 gravid female moths in each treatment under different stress conditions (Table $1 \& 2$ ). The results indicated that for bivoltine (Table.1) with Antenna\& wings amputation (T1) recorded 766 eggs on first day and 540 on second day totaling to 1306 amounting to $86.72 \%$. Egg retention for 5 months was 200 amounting to 
$13.28 \%$ and fecundity was 261 eggs per month. In T2 with legs and wings amputated indicated 539 eggs on first day and 363 on second day totaling to 902 and amounting to $86.15 \%$. Egg retention was 145 amounting to $13.85 \%$ and fecundity was 180 . In T3, with Antenna, legs \& wings cut indicated 1015 eggs on first day and 139 on second day totaling to 1154 and amounting to $89.53 \%$ and egg retention was 135 amounting to 10.47 $\%$ and fecundity of 231.In case of normal moths (T0), it was indicated 682 eggs on first day and 225 on second day totaling to 907 , amounting to $87.97 \%$ and eggs retention was 124 amounting to $12.03 \%$ per with a fecundity of 213 .

The results indicated for Trivoltine brood (Table.2) with Antenna\& wings amputation (T1) recorded 781 eggs on first day and 450 on second day totaling to 1231 amounting to95.42\%. Egg retention was 59 amounting to $4.57 \%$ and fecundity was 246 eggs. In T2 with legs and wings amputated indicated 516 eggs on first day and 316 on second day totaling to 832 and amounting to $85.15 \%$. Egg retention was 245 amounting to $25.07 \%$ and fecundity was 166 per month. In T3, with Antenna, legs \& wings cut indicated 833 eggs on first day and 293 on second day totaling to 1126 and amounting to $96.98 \%$ and egg retention was 35 amounting to $3.01 \%$ and fecundity of 225.In case of normal moths (T0), it was indicated 582 eggs on first day and 328 on second day totaling to 910 , amounting to $86.34 \%$ and eggs retention was 144 amounting to $13.66 \%$ with a fecundity of 182. The weight of male, female moths, single egg weight and eggs / $\mathrm{g}$ were recorded and depicted in Table 3 indicating 95 eggs / gm and 85 eggs / gm in bivoltine and trivoltine respectively.

The results on hatching in bivoltines were depicted in Table.4 indicating 91.25, 91.40, 88.95 and $90.20 \%$ in $\mathrm{T} 1, \mathrm{~T} 2, \mathrm{~T} 3$ and $\mathrm{T} 0$ respectively. The results on hatching in Trivoltine indicated 91.00, 90.00, 89.00 and $90.00 \%$ in $\mathrm{T} 1, \mathrm{~T} 2, \mathrm{~T} 3$ and $\mathrm{T} 0$ respectively.

Quality of Silkworm seed refers to richness of layings, egg viability and uniform hatching is indication for good performance of the progeny (Ullal and Narasimhanna, 1985). Several research workers have made attempts earlier to study different aspects of Tasar seed preservation for skipping unfavorable seasons (Jolly et al., 1974). Nayak and Dash (2001) have demonstrated the influence of climatological factors on reproduction of Tasar silk moth.

In the present investigation, when provided optimum temperature $\left(27-28^{\circ} \mathrm{C}\right)$ and humidity (75-80\%) in the egg laying room and egg laying carried out under stress conditions, number of eggs laid were improved in both bivoltine and trivoltine broods. In T1 where antenna and wings were amputated, the number of eggs recorded were 1306, in T2 (legs and wings cut) it were 902 and in T3 (antenna, wings \& legs cut), the number of laid eggs were 1154 and when compared to 907 in Normal (T0).Egg retention was also recorded and found to be less in treated batches (Table.1).

In case of Trivoltine also same pattern was observed (Table.2). In T1 where antenna and wings were amputated, the number of eggs recorded were 1231, in T2 (legs and wings cut) it were 832 and in T3 (antenna, wings \& legs cut), the number of laid eggs were 1126 and when compared to 910 in Normal (T0).

The Similar results of higher egg recovery was obtained by Kamaraj et al., (2014)where in it was mentioned that antenna amputated Tasar silk moths yielded more eggs during grainage operations and have shown improved hatching. But in the present investigation hatching was observed almost similar in all 
treatments irrespective of different stress (Table.3). Ravindra Singh et al., (2004), first time reported $10 \%$ increase in fecundity of antennae amputated female moths of mulberry silkworm and also suggested to carry out similar studies in Non-mulberry silkworms including Tasar silkworm.

Table.1 Egg laying efficiency in Bivoltine Tasar silk moths (sample 5 moths)

\begin{tabular}{|l|c|c|c|c|c|c|c|c|}
\hline Treatments & $\begin{array}{c}\mathbf{1}^{\text {st }} \\
\text { day }\end{array}$ & $\begin{array}{c}\mathbf{2}^{\text {nd }} \\
\text { day }\end{array}$ & \multicolumn{2}{|c|}{$\begin{array}{c}\text { Total laid } \\
\text { eggs }\end{array}$} & \multicolumn{2}{|c|}{$\begin{array}{c}\text { Egg retention in } \\
\text { the abdomen }\end{array}$} & $\begin{array}{c}\text { Total } \\
\text { eggs }\end{array}$ & $\begin{array}{c}\text { Fecundity } \\
\text { (No) }\end{array}$ \\
\hline $\begin{array}{l}\text { Antenna\& } \\
\text { wings cut } \\
\text { (T1) }\end{array}$ & 766 & 540 & 1306 & 86.72 & 200 & 13.28 & 1506 & 261 \\
\hline $\begin{array}{l}\text { Legs \&wings } \\
\text { cut (T2) }\end{array}$ & 539 & 363 & 902 & 86.15 & 145 & 13.85 & 1047 & 180 \\
\hline $\begin{array}{l}\text { Antenna, } \\
\text { wings \& legs } \\
\text { cut (T3) }\end{array}$ & 1015 & 139 & 1154 & 89.53 & 135 & 10.47 & 1289 & 231 \\
\hline
\end{tabular}

Table.2 Egg laying efficiency in Trivoltine Tasar moths (sample 5 moths)

\begin{tabular}{|c|c|c|c|c|c|c|c|c|}
\hline \multirow[t]{2}{*}{ Treatments } & \multirow[t]{2}{*}{$\begin{array}{l}1^{\text {st }} \\
\text { day }\end{array}$} & \multirow[t]{2}{*}{$\begin{array}{l}2^{\text {nd }} \\
\text { day }\end{array}$} & \multicolumn{2}{|c|}{$\begin{array}{c}\text { Total laid } \\
\text { eggs }\end{array}$} & \multicolumn{2}{|c|}{$\begin{array}{l}\text { Egg retention in } \\
\text { the abdomen }\end{array}$} & \multirow[t]{2}{*}{$\begin{array}{l}\text { Total } \\
\text { eggs }\end{array}$} & \multirow[t]{2}{*}{$\begin{array}{l}\text { Fecundity } \\
\text { (No) }\end{array}$} \\
\hline & & & No & $(\%)$ & No & $(\%)$ & & \\
\hline $\begin{array}{l}\text { Antenna\& } \\
\text { wings cut } \\
\text { (T1) }\end{array}$ & 781 & 450 & 1231 & 95.42 & 59 & 4.57 & 1290 & 246 \\
\hline $\begin{array}{l}\text { Legs \& wings } \\
\text { cut (T2) }\end{array}$ & 516 & 316 & 832 & 85.15 & 245 & 25.07 & 977 & 166 \\
\hline $\begin{array}{l}\text { Antenna, } \\
\text { wings \& legs } \\
\text { cut (T3) }\end{array}$ & 833 & 293 & 1126 & 96.98 & 35 & 3.01 & 1161 & 225 \\
\hline Normal (T0) & 582 & 328 & 910 & 86.34 & 144 & 13.66 & 1054 & 182 \\
\hline
\end{tabular}


Table.3 Weight of Tasar silkmoth (Average of 5 moths)

\begin{tabular}{|l|c|c|c|}
\hline \multicolumn{1}{|c|}{ Parameters } & Bivoltine & Trivoltine & Difference (\%) \\
\hline Weight of male moth (g) & 3.986 & 2.342 & $\mathbf{4 1 . 2 4}$ \\
\hline Weight of Female moth (g) & 8.286 & 6.998 & $\mathbf{1 5 . 5 4}$ \\
\hline Weight of single egg (mg) & 10.52 & 11.30 & $\mathbf{7 . 4 1}$ \\
\hline Eggs / gram (No) & $\mathbf{9 5}$ & $\mathbf{8 5}$ & $\mathbf{1 0}$ (Nos) \\
\hline
\end{tabular}

Table.4 Effect of treated eggs on hatching in Tasar silkworm

\begin{tabular}{|l|c|c|c|c|}
\hline \multicolumn{1}{|c|}{ Treatments } & \multicolumn{2}{|c|}{ Bivoltine eggs / g.95 } & \multicolumn{2}{c|}{ Trivoltine eggs /g.85 } \\
\cline { 2 - 5 } & Eggs kept & Hatching \% & Eggs kept & Hatching \% \\
\hline $\begin{array}{l}\text { Antenna \& } \\
\text { wings cut (T1) }\end{array}$ & 475 & 91.25 & 425 & $\mathbf{9 1 . 0 0}$ \\
\hline $\begin{array}{l}\text { Legs and wings } \\
\text { cut (T2) }\end{array}$ & 475 & 91.40 & 425 & $\mathbf{9 0 . 0 0}$ \\
\hline $\begin{array}{l}\text { Antenna, wings } \\
\text { \& legs cut (T3) }\end{array}$ & 475 & 88.95 & 425 & $\mathbf{8 9 . 0 0}$ \\
\hline Normal (T0) & $\mathbf{4 7 5}$ & $\mathbf{9 0 . 2 0}$ & $\mathbf{4 2 5}$ & $\mathbf{9 0 . 0 0}$ \\
\hline
\end{tabular}

It is clear from the results that in treated batches $\mathrm{T} 1$ and $\mathrm{T} 3$, where amputation of antennae involved, the eggs laid were more indicating importance of antenna in egg laying when compared to other batches where Antenna amputation was not involved (T2 and T0). Morohoshi (2000) reported that among the four groups of secretary cells laterally located in the hind brain, the IV group consists of 3 Neuro- secretary cells are directly linked to the antennae on the head and their secretion passes through outer axon and reaches the corpus cardiacum where it stimulates the organs and regulates its function.

It is concluded that when stress was given in the form of body parts amputation, the Neurohormones may give signal to the brain and stimulate to lay whatever eggs remained in the abdomen. This type of stress conditions mentioned above may be practiced during grainage operations of Tasar silk moth for improved egg laying and fecundity.

\section{Acknowledgement}

The Authors are thankful to Dr.G.Vemananda Reddy, Former Scientist D of this institute for his valuable guidance and help during the Study.

\section{References}

Chapman, R.F. (1998) The Insects structure and function, Fourth edn.,Cambridge University Press pp.8-11.

Jolly,M.S., Sen S.K., and Ahsan, M.M (1974) Tasar culture (First edn.) Central Silk Board, Bombay, India.pp 1-266.

Kamaraj, S; Tiwari, M.D; Minakshi, M, Shabnam, N.K, Madhusudhan, K.N, Serani, K Sharma, S.P and Alok Sahay 
(2014). Studies on effect of antenna amputation on the fecundity and hatching performance of tropical tasarsilk moths during grainage operations. J.ofchem.bio. and phy.science (JCBPS)..5(1). 960-963.

Morohoshi, S (2000). Development Physiology of Silkworms. Oxford \& IBH publishing Co. Pvt. Ltd. New Delhi, Calcutta.

Nayak. B. M., Patro K.B.G. and Dash, M.C. (2001). Selection of ideal grainage house for preservation of diapausing seed cocoons of the topical Tasar silk moth, Antheraea paphia Linn. Bull Ind. Acad. Seri. 5:9-15.

Pandey, J.P, P.K.Mishra, D.Kumar, B.M. K. Singh and B.C.Prasad (2010) Effect of Temperature on Haemocytic immune responses of tropical Tasar Silkworm Antheraea mylitta D. Research.J.Immunol., 3: 169-177.

Ravindra Singh, Virendra Kumar, Kariappa, B.K, Dandin, S.B and D. Raghavendra
Rao (2004). Stimulation of fecundity through Antennal amputation in the Mulberry silkworm, Bombyx mori L. I.J.I.E, 8 (2): 217-219.

Ravindranath Singh, Manoj Kumar Sinha, Chandra Mouli Bajpeyi, Ajit Kumar Sinha, Amalendu Tikader (2014). Tasar Culture, published by APH publishing corporation, New Delhi.pp.266-270.

Ullal, S and Narasimhanna, M. N. (1985). Hand book of Sericulture, Central silk Board, Bombay, India, pp. 1-94.

Vemananda Reddy;G., Jayappa, $\mathrm{T}$ and Ravindra Singh (2016) Studies on egg production and egg handling techniques in Tasar Silkworm Antheraea mylitta. D. Annual report SSTL,(2015-16).,SSTL, Central silk Board, Bangalore, India.

Zacharuk, R.Y (1985). Antennae and sensilla ; in Comprehensive Insect Physiology, Biochemistry and Pharmacology.6; Kerkkut, G. A. and L.I Gilbert (eds),pp169, Oxford.

\section{How to cite this article:}

Sudhakara Rao, P., K. M. Vijaya Kumari, B. Sailaja, G. V. Vishaka, S. Vidyunmala and Mishra, R. K. 2019. Studies on Egg Laying Behaviuor and Fecundity under Different Stress Conditions in Tropical Tasar Silk Moth. Int.J.Curr.Microbiol.App.Sci. 8(09): 1182-1187. doi: https://doi.org/10.20546/ijcmas.2019.809.135 